\title{
Anti-tyrosinase and Anti-butyrylcholinesterase Quinolines-Based Coumarin Derivatives: Synthesis and Insights from Molecular Docking Studies
}

\author{
Marwa Gardelly $^{1} \cdot$ Belsem Trimech $^{1} \cdot$ Mabrouk Horchani $^{1} \cdot$ Mansour Znati $^{1} \cdot$ Hichem Ben Jannet $^{1} \cdot$ Anis Romdhane $^{1}$
}

Received: 18 January 2021 / Accepted: 25 February 2021 / Published online: 8 March 2021

(C) The Tunisian Chemical Society and Springer Nature Switzerland AG 2021

\begin{abstract}
In this work, a series of anti-tyrosinase and anti-butyrylcholinesterase coumarin derivatives $4 \mathbf{a}-\mathbf{f}$ and $\mathbf{5 a}-\mathbf{f}$ were synthesized starting from 4-hydroxycoumarin. The condensation of 2-(arylimin)-4-hydroxycoumarins 3a-f with dimethylformamide dimethyl acetal (DMF-DMA), used as a key reaction, afforded the precursors $\mathbf{4 a - f}$, whose acid treatment led to the formation of $\mathbf{5 a}-\mathbf{f}$. These prepared heterocycles were characterized by spectroscopic means including ${ }^{1} \mathrm{H}-\mathrm{NMR},{ }^{13} \mathrm{C}-\mathrm{NMR}$, and DCI-HRMS. Their anti-tyrosinase and anti-butyrylcholinesterase activities have been evaluated in vitro and some of them exhibited promising activity supported by the molecular docking analysis to estimate possible interactions between these compounds and active sites of both proteins tyrosinase (PDB: 2Y9W) and butyrylcholinesterase (PDB: 4TPK).
\end{abstract}

Keywords Quinoline $\cdot$ Coumarin $\cdot$ Bioactivity $\cdot$ Molecular docking $\cdot$ SAR

\section{Introduction}

Alzheimer's disease (AD) is a neurodegenerative disorder characterized by memory loss, behavioral abnormalities, and cognitive impairments [1]. Generally, individuals with this type of neurological disorder are elderly. The ultimate cause of memory deterioration is acetylcholine and butyrylcholine deficiency [2] in the parts of the central nervous system that mediate learning and memory functions. Many therapeutic approaches have been taken in an attempt to discover agents to treat and prevent AD [3]. Despite the development of therapies, treatment is still unsatisfactory, because of the limited efficiency of BChE inhibitors, including Tacrine [4, 5], Rivastigmine [6], and Galanthamine [7]. Nitrogen heterocyclic compounds, such as quinoline derivatives, can act as effective anticholinesterase agents [8], and may substantially improve AD symptoms [9-11]. Recently, many reports covering the development in quinoline synthesis have been

Anis Romdhane

anis_romdhane@yahoo.fr

1 Laboratory of Heterocyclic Chemistry, Natural Products and Reactivity, Faculty of Science of Monastir, Team: Medicinal Chemistry and Natural Products, Avenue of Environment, University of Monastir, 5019 Monastir, Tunisia published [12-15]. Quinolines, such as chloroquinine and quinine salicylate were also identified as potent inhibitors of tyrosinase [16]. The latter is a key enzyme involved in melanin biosynthesis, which is responsible for skin pigmentation [17] and plays an important role in protection against UV radiation. Many studies have shown that pigmentation disorders due to high levels of melanin can cause serious dermatological damages [18]. Skin damage is a major reason behind restricted usage of certain pharmaceuticals.

Previous research revealed that 3 -substituted coumarin derivatives are very attractive scaffolds for the development of therapeutic compounds [19-22]. In addition, their anticholinesterase and anti-Alzheimer abilities are wellknown [23]. A review of structure-activity relationships (SARs) indicated that chromone compounds possess good tyrosinase inhibitory potential due to their structural similarity to flavonoids, which combat pigment disorders [24].

Building on previous research, we decided to merge two pharmacophores: a differently substituted quinoline moiety to a coumarin entity, with the aim to discover original hybrid bioactive agents that inhibit tyrosinase and butyrylcholinesterase enzymes, and to discuss the structure-activity relationship (SAR) using molecular docking analysis. With this in mind, a series of substituted 4-hydroxy-3-(quinolin2-yl)-2H-chromen-2-one derivatives $\mathbf{5 a - f}$ were synthesized. 


\section{Experimental Section}

DCI-HRMS (Desorption Chemical Ionization-High Resolution Mass Spectrometry) has been run in a GCT Premier Mass Spectrometer (Waters). ${ }^{1} \mathrm{H}(300 \mathrm{MHz})$ and ${ }^{13} \mathrm{C}$ (75 MHz) NMR spectra have been recorded on a Bruker AM-300 spectrometer, using $\mathrm{CDCl}_{3}$ or DMSO- $d_{6}$ as solvent and none deuterated residual solvent as internal standard. Chemicals shifts $(\delta)$ are given in parts per million (ppm) and coupling constants $(J)$ in Hertz. Melting points have been determined on a Büchi 510 apparatus using capillary tubes and are uncorrected.

\section{Chemistry}

\subsection{General Procedure for the Synthesis of Compound 2}

4-hydroxy-2H-chromen2-one (1, $4 \mathrm{~g}, 24.8 \mathrm{mmol})$ was dissolved in anhydride acetic $(15 \mathrm{~mL})$ and pyridine $(5 \mathrm{~mL})$ at room temperature. The resulted solution was brought to refux temperature for $45 \mathrm{~min}$. After cooling, the reaction crude was precipitated and collected by filtration after several washing with distilled water. The recuperated yellow solid was then recrystallized from ethanol yielding compound $\mathbf{2}$ as white crystals.

\subsection{Spectral Data of Compound 2}

\subsubsection{3-Acetyl-4-Hydroxy-2H-Chromen-2-One (2)}

Yield: 95\%, MP: $135-137{ }^{\circ} \mathrm{C} ;{ }^{1} \mathrm{H} \mathrm{NMR}\left(300 \mathrm{MHz}, \mathrm{CDCl}_{3}\right.$, $\delta): 2.78\left(\mathrm{~s}, 3 \mathrm{H}, \mathrm{CH}_{3}\right), 7.30(\mathrm{dd}, 1 \mathrm{H}, \mathrm{H}-8, J=8.3$ and $0.9 \mathrm{~Hz})$, $7.35(\mathrm{td}, 1 \mathrm{H}, \mathrm{H}-6, J=7.6$ and $0.9 \mathrm{~Hz}),, 7.70 \mathrm{(td}, 1 \mathrm{H}, \mathrm{H}-7$, $J=8.3$ and $1.5 \mathrm{~Hz}$ ), 8.05 (dd, $1 \mathrm{H}, \mathrm{H}-5, J=7.6$ and $1.5 \mathrm{~Hz}$ ), 17.70 (s, $1 \mathrm{H}, \mathrm{OH}) .{ }^{13} \mathrm{C} \mathrm{NMR}\left(75 \mathrm{MHz}, \mathrm{CDCl}_{3}, \delta\right): 30.2$ $\left(\mathrm{CH}_{3}\right), 101.93$ (C-3), 115.2 (C-4a), 117.3 (C-8), 125.3 (C-5), 125.7 (C-6), 134.2 (C-7), 154.6 (C-8a), 159.7 (C-2), 178.4 (C-4), 205.97 (CO).

\subsection{General Procedure for the Synthesis of Com- pounds $4 a-f$ and $5 a-f$}

Five hundred milligrams (0.002 mol) of 3-acetyl-4-hydroxycoumarin 2 and $227 \mathrm{mg}(0.002 \mathrm{~mol})$ of mono-substituted anilines were added to a $100 \mathrm{~mL}$ flask in $50 \mathrm{~mL}$ of ethanol. After 2 h of reflux, imines 3 were formed; they were filtered and washed with ethanol then treated with 2 eq. of dimethylformamide dimethyl acetal (DMF-DMA) $(0.3 \mathrm{~mL})$ in toluene $(5 \mathrm{~mL})$ for $10 \mathrm{~min}$ to form the enaminic intermediate
4 [25, 26]. The reaction was visualized using thin-layer chromatography (Elution System: EtOAc) showing the disappearance of the starting material and the appearance the major polar product. After evaporation of toluene, intermediates $\mathbf{4 a - f}$ (obtained by precipitation), were brought to reflux in $5 \mathrm{~mL}$ of acetic acid for $1 \mathrm{~h}$. The reaction crude was then precipitated in distilled water and collected by filtration to afford compounds $\mathbf{5 a}-\mathbf{f}$ (See supplementary materials for spectral data of compounds $\mathbf{4 a - f}$ and $\mathbf{5 a} \mathbf{a}-\mathbf{f})$.

\subsection{Spectral Data of Compounds 4a-f and 5a-f}

3-((1E,2E)-3-(dimethylamino)-1-(phenylimino)allyl)4-hydroxy-2H-chromen-2-one (4a) Yield: 53\%, MP: 200-202 ${ }^{\circ} \mathrm{C},{ }^{1} \mathrm{H}$ NMR (300 MHz, $\mathrm{CDCl}_{3}, \delta$ ): 2.48 (s, $\left.6 \mathrm{H}, \mathrm{N}\left(\mathrm{CH}_{3}\right)_{2}\right), 5.78$ (d, 1H, H-3', J=12 Hz), $7.04(\mathrm{~d}, 2 \mathrm{H}$, H-2",6", J=6 Hz), 7.08 (m, 3H, H-4",6,8), 7.19 (m, 3H, H-3",5",7), 7.34 (m, 1H, H-5), 7.94 (d, 1H, H-4', J=12 Hz), $12.77(\mathrm{~s}, 1 \mathrm{H}, \mathrm{OH}) ;{ }^{13} \mathrm{C} \mathrm{NMR}\left(75 \mathrm{MHz}, \mathrm{CDCl}_{3}, \delta\right): 42.6$ $\left(\mathrm{N}\left(\mathrm{CH}_{3}\right)_{2}\right), 88.2(\mathrm{C}-3), 93.0\left(\mathrm{C}-3^{\prime}\right), 115.6(\mathrm{C}-4 \mathrm{a}), 116.4$ (C-8), 121.0 (C-5), 122.5 (C-2",6"), 125.2 (C-6), 126.0 (C-4"), 129.0 (C-3",5"), 131.9 (C-7), 148.5 (C-2'), 150.2 (C-8a), 160.7 (C-2), 163.0 (C-4'), 168.3 (C-4). DCI-HRMS $[\mathrm{M}+\mathrm{H}]^{+}$calcd. for $\left(\mathrm{C}_{20} \mathrm{H}_{19} \mathrm{~N}_{2} \mathrm{O}_{3}\right)^{+}: 335.1395$, found 335.1405 .

\subsubsection{3-((1E,2E)-1-((4-Chlorophenyl) imino)-3-(Dimethylamino)allyl)-4-Hy- droxy-2H-cChromen-2-One (4b)}

Yield: 63\%, MP: 202-204 ${ }^{\circ} \mathrm{C},{ }^{1} \mathrm{H}$ NMR (300 MHz, $\mathrm{CDCl}_{3}$, $\delta): 2.97\left(\mathrm{~s}, 6 \mathrm{H}, \mathrm{N}\left(\mathrm{CH}_{3}\right)_{2}\right), 5.74\left(\mathrm{~d}, 1 \mathrm{H}, \mathrm{H}-3^{\prime}, J=12 \mathrm{~Hz}\right), 7.05$ (d, 2H, H-2",6", J=6 Hz), 7.15 (td, 1H, H-7, J=6;0.9 Hz), 7.20 (m, 2H, H-6,8), 7.34 (d, 2H, H-3",5", J=6 Hz), 7.39 (d, 1H, H-4', J=12 Hz), 8.00 (d, 1H, H-5, J=9 Hz), 12.65 (s, $1 \mathrm{H}, \mathrm{OH}) ;{ }^{13} \mathrm{C} \mathrm{NMR}\left(75 \mathrm{MHz}, \mathrm{CDCl}_{3}, \delta\right): 43.3\left(\mathrm{~N}\left(\mathrm{CH}_{3}\right)_{2}\right)$, 88.5 (C-3), 94.0 (C-3'), 115.2 (C-4a), 116.0 (C-8), 120.0 (C-5), 122.1 (C-2",6"), 122.6 (C-6), 125.7 (C-7), 129.1 (C-3",5"), 131.9 (C-4"), 147.7 (C-1"), 148.5 (C-2'), 151.1 (C-8a), 160.5 (C-2), 162.9 (C-4'), 167.9 (C-4). DCI-HRMS $[\mathrm{M}+\mathrm{H}]^{+}$calcd. for $\left(\mathrm{C}_{20} \mathrm{H}_{18} \mathrm{ClN}_{2} \mathrm{O}_{3}\right)^{+}: 369.1006$, found 369.1017 .

\subsubsection{3-((1E,2E)-3-(Dimethylamino)-1-(p-Tolylimino) allyl)-4-Hydroxy-2H-Chromen-2-One (4c)}

Yield: 60\%, MP: 200-202 ${ }^{\circ} \mathrm{C},{ }^{1} \mathrm{H}$ NMR (300 MHz, $\mathrm{CDCl}_{3}$, $\delta): 2.34$ (s, 3H, $\mathrm{CH}_{3}$ ), 2.87 (s, ${ }^{2} \& \mathrm{a} 7.30$ (m, 2H, H-6,8), 7.41 (d, 2H, H-3",5", J=6 Hz) 8.02 (d, 1H, H-4', J=12 Hz), $8.04(\mathrm{~d}, 1 \mathrm{H}, \mathrm{H}-5, J=9 \mathrm{~Hz}), 12.42(\mathrm{~s}, 1 \mathrm{H}, \mathrm{OH}) ;{ }^{13} \mathrm{C} \mathrm{NMR}$ $\left(75 \mathrm{MHz}, \mathrm{CDCl}_{3}, \delta\right): 20.7\left(\mathrm{CH}_{3}\right), 43.0\left(\mathrm{~N}\left(\mathrm{CH}_{3}\right)_{2}\right), 88.5$ (C-3), 92.0 (C-3'), 115.6 (C-4a), 116.0 (C-8), 120.9 (C-5), (121.7) (C-2",6"), 125.1 (C-6), 129.4 (C-3",5"), 128.7 (C-7), 
134.8 (C-4"), 146.4 (C-1"), 147.0 (C-2'), 151.0 (C-8a), 159.7 (C-2), $162.5\left(\mathrm{C}-4^{\prime}\right), 168.4(\mathrm{C}-4)$. DCI-HRMS $[\mathrm{M}+\mathrm{H}]^{+}$calcd. for $\left(\mathrm{C}_{21} \mathrm{H}_{21} \mathrm{~N}_{2} \mathrm{O}_{3}\right)^{+}: 349.1552$, found 349.1564.

\subsubsection{3-((1E,2E)-3-(Dimethylamino)-1-((4-Methoxyphenyl) imino)allyl)-4-Hydroxy-2H Chromen-2-One (4d)}

Yield: 57\%, MP: $200-202{ }^{\circ} \mathrm{C},{ }^{1} \mathrm{H}$ NMR $\left(300 \mathrm{MHz}, \mathrm{CDCl}_{3}\right.$, $\delta): 2.97\left(\mathrm{~s}, 6 \mathrm{H}, \mathrm{N}\left(\mathrm{CH}_{3}\right)_{2}\right), 3.78\left(\mathrm{~s}, 3 \mathrm{H}, \mathrm{OCH}_{3}\right), 5.58(\mathrm{~d}, 1 \mathrm{H}$, H-3', $J=12 \mathrm{~Hz}$ ), 6.84 (d, 2H, H-3",5", $J=9 \mathrm{~Hz}), 7.03$ (d, $\left.2 \mathrm{H}, \mathrm{H}-2^{\prime \prime}, 6^{\prime \prime}, J=9 \mathrm{~Hz}\right), 7.11$ (m, 2H, H-6,8), 7.30 (m, 2H, $\left.\mathrm{H}-4^{\prime}, 7\right), 7.96$ (d, 1H, H-5, $\left.J=9 \mathrm{~Hz}\right), 12.20(\mathrm{~s}, 1 \mathrm{H}, \mathrm{OH}) ;{ }^{13} \mathrm{C}$ NMR $\left(75 \mathrm{MHz}, \mathrm{CDCl}_{3}, \delta\right): 40.9\left(\mathrm{~N}\left(\mathrm{CH}_{3}\right)_{2}\right), 54.9\left(\mathrm{OCH}_{3}\right)$, 88.1 (C-3), 93.7 (C-3'), 114.7 (C-4a), $115.6\left(\mathrm{C}-3^{\prime \prime}, 5^{\prime \prime}\right)$, 116.0 (C-8), 121.0 (C-5), $122.3\left(\mathrm{C}-2^{\prime \prime}, 6^{\prime \prime}\right), 123.1$ (C-6), 131.4 (C-7), $141.6\left(\mathrm{C}-1^{\prime \prime}\right), 148.7$ (C-2'), 152.2 (C-8a), 160.1 (C-4"), 160.8 (C-2), 162.7 (C-4'), 167.5 (C-4). DCIHRMS $[\mathrm{M}+\mathrm{H}]^{+}$calcd. for $\left(\mathrm{C}_{21} \mathrm{H}_{21} \mathrm{~N}_{2} \mathrm{O}_{4}\right)^{+}: 368.1308$, found 368.1319 .

\subsubsection{3-((1E,2E)-3-(Dimethylamino)-1-((4-Ethoxyphenyl) imino)allyl)-4-Hydroxy-2H-Chromen-2-One (4e)}

Yield: $61 \%$, MP: $200-202{ }^{\circ} \mathrm{C},{ }^{1} \mathrm{H}$ NMR $\left(300 \mathrm{MHz}, \mathrm{CDCl}_{3}\right.$, $\delta): 1.22\left(\mathrm{~s}, 3 \mathrm{H}, \mathrm{CH}_{3}-(\mathrm{a})\right), 2.62\left(\mathrm{q}, 2 \mathrm{H}, \mathrm{CH}_{2}-(\mathrm{b}), J=7.5 \mathrm{~Hz}\right)$, $2.92\left(\mathrm{~s}, 6 \mathrm{H}, \mathrm{N}\left(\mathrm{CH}_{3}\right)_{2}\right), 5.76\left(\mathrm{~d}, 1 \mathrm{H}, \mathrm{H}-3^{\prime}, J=12 \mathrm{~Hz}\right), 7.10$ (d, 2H, H-2", 6", $J=9 \mathrm{~Hz}), 7.18$ (d, 2H, H-3",5", $J=9 \mathrm{~Hz}$ ), 7.23 (m, 2H, H-6,8), 7.34 (m, 2H, H-4',7), 8.02 (d, 1H, H-5, $J=9 \mathrm{~Hz}), 12.40(\mathrm{~s}, 1 \mathrm{H}, \mathrm{OH}) ;{ }^{13} \mathrm{C}$ NMR $\left(75 \mathrm{MHz}, \mathrm{CDCl}_{3}\right.$, $\delta): 15.0\left(\mathrm{CH}_{3}-(\mathrm{a})\right), 42.9\left(\mathrm{~N}\left(\mathrm{CH}_{3}\right)_{2}\right), 64.2\left(\mathrm{CH}_{2}-(\mathrm{b})\right), 88.2$ (C-3), 92.0 (C-3'), 115.6 (C-4a), 116.5 (8), 121.1 (C-5), $117.6\left(\mathrm{C}-2^{\prime \prime}, \mathrm{C}-6^{\prime \prime}\right), 121.3\left(\mathrm{C}-3^{\prime \prime}, 5^{\prime \prime}\right), 122.5$ (C-6), 128.1 (7), 142.4 (C-1"), 147.9 (C-2'), 152.2 (C-8a), 154.2 (C-4"), $159.9(\mathrm{C}-2), 163.3\left(\mathrm{C}-4^{\prime}\right), 168.5$ (C-4). DCI-HRMS [M+H] ${ }^{+}$ calcd. for $\left(\mathrm{C}_{22} \mathrm{H}_{23} \mathrm{~N}_{2} \mathrm{O}_{4}\right)^{+}: 379.1658$, found 379.1670 .

\subsubsection{3-((1E,2E)-1-((3-Chlorophenyl) imino)-3-(Dimethylamino)allyl)-4-Hy- droxy-2H-Chromen-2-One (4f)}

Yield: 76\%, MP: $202-204{ }^{\circ} \mathrm{C},{ }^{1} \mathrm{H}$ NMR $\left(300 \mathrm{MHz}, \mathrm{CDCl}_{3}\right.$, $\delta): 2.83\left(\mathrm{~s}, 6 \mathrm{H}, \mathrm{N}\left(\mathrm{CH}_{3}\right)_{2}\right), 5.75\left(\mathrm{~d}, 1 \mathrm{H}, \mathrm{H}-3^{\prime}, J=12 \mathrm{~Hz}\right)$, 6.95 (d, 1H, H-6", $J=9 \mathrm{~Hz}$ ), 7.09 (m, 2H, H-6,8), 7.32 (m, 2H, H-4', 7), 7.47 (d, 1H, H-4", J=9 Hz), 7.57 (t, 1H, H-5", $J=9 \mathrm{~Hz}), 7.85$ (s, 1H, H-2"), 7.91 (d, 1H, H-5, $J=9 \mathrm{~Hz}$ ), $12.40(\mathrm{~s}, 1 \mathrm{H}, \mathrm{OH}) ;{ }^{13} \mathrm{C}$ NMR $\left(75 \mathrm{MHz}, \mathrm{CDCl}_{3}, \delta\right): 44.0$ $\left(\mathrm{N}\left(\mathrm{CH}_{3}\right)_{2}\right), 88.6(\mathrm{C}-3), 94.0\left(\mathrm{C}-3^{\prime}\right), 115.5(\mathrm{C}-4 \mathrm{a}), 116.7$ (C-8), 120.9 (C-6"), 122.4 (C-2"), 122.6 (C-5), 124.3 (C-6), 125.9 (C-4"), 129.9 (C-7), 131.7 (C-5"), 134.4 (C-3"), 148.0 (C-2'), 152.9 (C-1"), 153.2 (C-8a), 162.0 (C-2), $163.1\left(\mathrm{C}^{-} 4^{\prime}\right), 167.5$ (C-4). DCI-HRMS [M+H] ${ }^{+}$calcd. for $\left(\mathrm{C}_{20} \mathrm{H}_{18} \mathrm{ClN}_{2} \mathrm{O}_{3}\right)^{+}:$369.1006, found 369.1011.
3.4.6 4-Hydroxy-3-(Quinolin-2-yl)-2H-Chromen-2-One (5a)

Yield: 52\%, MP: $300-302{ }^{\circ} \mathrm{C},{ }^{1} \mathrm{H}$ NMR $(300 \mathrm{MHz}$, DMSO$\left.d_{6}, \delta\right): 7.17(\mathrm{~m}, 1 \mathrm{H}, \mathrm{H}-6), 7.22(\mathrm{~m}, 1 \mathrm{H}, \mathrm{H}-8), 7.34(\mathrm{~m}, 4 \mathrm{H}$, H-5,7,5',3'), 7.71 (m,1H, H-6'), 7.81 (s, 1H, H-7'), 7.96 (d, $\left.1 \mathrm{H}, \mathrm{H}-4^{\prime}, J=6 \mathrm{~Hz}\right), 8.68$ (d, $\left.1 \mathrm{H}, \mathrm{H}-8^{\prime}, J=6 \mathrm{~Hz}\right), 11.37$ (s, $1 \mathrm{H}, \mathrm{OH}) ;{ }^{13} \mathrm{C}$ NMR $\left(75 \mathrm{MHz}, \mathrm{DMSO}-d_{6}, \delta\right): 97.6(\mathrm{C}-3)$, 116.4 (C-8), 117.4 (C-4a), 119.8 (C-3'), 123.3 (C-5), 123.8 (C-6), 125.6 (C-6'), 128.3 (C-4'a), 128.7 (C-5'), 130.4 (C-7), $131.7\left(\mathrm{C}-8^{\prime}\right), 132.1$ (C-7'), 135.4 (C-4'), 146.7 (C-8'a), 152.5 (C-8a), 159.1 (C-2'), 161.9 (C-2), 166.4 (C-4). DCIHRMS $[\mathrm{M}+\mathrm{H}]^{+}$calcd. for $\left(\mathrm{C}_{18} \mathrm{H}_{12} \mathrm{NO}_{3}\right)^{+}: 290.0817$, found 290.0825 .

\subsubsection{3-(6-Chloroquinolin-2-yl)-4-Hy- droxy-2H-Chromen-2-One (5b)}

Yield: 71\%, MP: $300-302{ }^{\circ} \mathrm{C},{ }^{1} \mathrm{H}$ NMR (300 MHz, DMSO$\left.d_{6}, \delta\right): 7.33\left(\mathrm{~m}, 6 \mathrm{H}, \mathrm{H}-3^{\prime}, 5^{\prime}, 5,6,7,8\right), 7.71\left(\mathrm{~s}, 1 \mathrm{H}, \mathrm{H}-7^{\prime}\right), 7.99$ $\left(\mathrm{d}, 1 \mathrm{H}, \mathrm{H}-4^{\prime}, J=6 \mathrm{~Hz}\right), 8.06\left(\mathrm{~d}, 1 \mathrm{H}, \mathrm{H}-8^{\prime}, J=9 \mathrm{~Hz}\right), 11.37$ (s, $1 \mathrm{H}, \mathrm{OH}) ;{ }^{13} \mathrm{C}$ NMR (75 MHz, DMSO- $d_{6}, \delta$ ): $97.6(\mathrm{C}-3)$, 116.4 (C-8), 117.4 (C-4a), 119.8 (C-3'), 123.3 (C-5), 123.7 (C-5'), 125.1 (C-6), 128.0 (C-7), 128.7 (C-4'a), 130.2 (C-8'), 131.5 (C-7'), 132.4 (C-6'), 135.8 (C-4'), 146.0 (C-8'a), 151.8 (C-8a), 159.5 (C-2'), 161.7 (C-2), 166.7 (C-4). DCI-HRMS $[\mathrm{M}+\mathrm{H}]^{+}$calcd. for $\left(\mathrm{C}_{18} \mathrm{H}_{11} \mathrm{ClNO}_{3}\right)^{+}: 324.0427$, found 324.0438 .

\subsubsection{4-Hydroxy-3-(6-Methylquino- lin-2-yl)-2H-Chromen-2-One (5c)}

Yield: 45\%, MP: $260-262{ }^{\circ} \mathrm{C},{ }^{1} \mathrm{H}$ NMR $(300 \mathrm{MHz}$, DMSO$\left.d_{6}, \delta\right): 2.30$ (s, $\left.3 \mathrm{H}, \mathrm{CH}_{3}\right), 6.89$ (m, 3H, H-6,8,8'), 7.19 (m, $\left.3 \mathrm{H}, \mathrm{H}-7,3^{\prime}, 6^{\prime}\right), 7.54$ (d, 1H, H-4', J=6 Hz), 7.98 (d, 1H, H-7', $J=6 \mathrm{~Hz}), 11.14(\mathrm{~s}, 1 \mathrm{H}, \mathrm{OH}) ;{ }^{13} \mathrm{C}$ NMR $(75 \mathrm{MHz}, \mathrm{DMSO}-$ $\left.d_{6}, \delta\right): 21.4\left(\mathrm{CH}_{3}\right), 95.0(\mathrm{C}-3), 114.0(\mathrm{C}-8), 116.6(\mathrm{C}-4 \mathrm{a})$, 117.8 (C-3'), 123.9 (C-5), 125.1 (C-5'), 128.7 (C-4'a), 128.9 (C-6), 129.3 (C-8'), 129.7 (C-7), 131.7 (C-7'), 134.7 (C-4'), 135.7 (C-6'), 146.0 (C-8'a), 152.5 (C-8a), 154.1 (C-2'), $160.0(\mathrm{C}-2), 168.4(\mathrm{C}-4)$. DCI-HRMS $[\mathrm{M}+\mathrm{H}]^{+}$calcd. for $\left(\mathrm{C}_{19} \mathrm{H}_{14} \mathrm{NO}_{3}\right)^{+}:$304.0974, found 304.0988.

\subsubsection{4-Hydroxy-3-(6-Methoxyquino- lin-2-yl)-2H-Chromen-2-One (5d)}

Yield: 75\%, MP: $260-262{ }^{\circ} \mathrm{C},{ }^{1} \mathrm{H}$ NMR $(300 \mathrm{MHz}$, DMSO$\left.d_{6}, \delta\right): 3.78\left(\mathrm{~s}, 3 \mathrm{H}, \mathrm{OCH}_{3}\right), 6.97\left(\mathrm{~m}, 2 \mathrm{H}, \mathrm{H}-5^{\prime}, 7^{\prime}\right), 7.19(\mathrm{~d}$, $\left.1 \mathrm{H}, \mathrm{H}-3^{\prime}, J=6 \mathrm{~Hz}\right), 7.29$ (m, 3H, H-6,7,8), 7.68 (t, 1H, H-5, $J=6 \mathrm{~Hz}), 7.97\left(\mathrm{~d}, 1 \mathrm{H}, \mathrm{H}-8^{\prime}, J=6 \mathrm{~Hz}\right), 8.57\left(\mathrm{~d}, 1 \mathrm{H}, \mathrm{H}-4^{\prime}\right.$, $J=6 \mathrm{~Hz}), 11.24(\mathrm{~s}, 1 \mathrm{H}, \mathrm{OH}) ;{ }^{13} \mathrm{C}$ NMR $(75 \mathrm{MHz}, \mathrm{DMSO}-$ $\left.d_{6}, \delta\right): 55.3\left(\mathrm{OCH}_{3}\right), 95.3(\mathrm{C}-3), 104.9\left(\mathrm{C}-5^{\prime}\right), 115.9(\mathrm{C}-8)$, 117.1 (C-4a), 119.0 (C-3'), 121.1 (C-7'), 123.0 (C-5), 125.4 (C-6), 127.1 (C-7), 128.9 (C-4'a), 131.5 (C-8'), 134.7 (C-4'), 
143.5 (C-8'a), 153.3 (C-8a), 156.7 (C-6'), 157.4 (C-2'), 160.7 (C-2), 168.5 (C-4). DCI-HRMS [M+H] ${ }^{+}$calcd. for $\left(\mathrm{C}_{19} \mathrm{H}_{14} \mathrm{NO}_{4}\right)^{+}:$320.0923, found 320.0927 .

\subsubsection{3-(6-Ethoxyquinolin-2-yl)-4-Hy- droxy-2H-Chromen-2-One (5e)}

Yield: 48\%, MP: $270-272{ }^{\circ} \mathrm{C},{ }^{1} \mathrm{H}$ NMR $(300 \mathrm{MHz}$, DMSO$\left.d_{6}, \delta\right): 1.11$ (t, $3 \mathrm{H}, \mathrm{CH}_{3}$-(a), $\left.J=2.7 \mathrm{~Hz}\right), 2.58\left(\mathrm{q}, 2 \mathrm{H}, \mathrm{CH}_{2-}(\mathrm{b})\right.$, $J=6 \mathrm{~Hz}), 7.26\left(\mathrm{~m}, 6 \mathrm{H}, \mathrm{H}-5,6,7,8,6^{\prime}, 8^{\prime}\right), 7.46\left(\mathrm{~d}, 1 \mathrm{H}, \mathrm{H}-3^{\prime}\right.$, $J=6 \mathrm{~Hz}), 7.68\left(\mathrm{~d}, 1 \mathrm{H}, \mathrm{H}-4^{\prime}, J=6 \mathrm{~Hz}\right), 8,63\left(\mathrm{~d}, 1 \mathrm{H}, \mathrm{H}-7^{\prime}\right.$, $J=6 \mathrm{~Hz}), 11,37(\mathrm{~s}, 1 \mathrm{H}, \mathrm{OH}) ;{ }^{13} \mathrm{C}$ NMR $\left(75 \mathrm{MHz}\right.$, DMSO- $d_{6}$, $\delta): 14.5\left(\mathrm{CH}_{3-}\right.$ (a)), $64.4\left(\mathrm{CH}_{2-}\right.$ (b)), $95.8(\mathrm{C}-3), 106.1\left(\mathrm{C}-5^{\prime}\right)$, 116.0 (C-8), 116.4 (C-4a), 117.5 (C-3'), 122.1 (C-7'), 124.0 (C-5), 127.3 (C-6), 129.0 (C-7), 129.7 (C-4'a), 130.5 (C-8'), 134.7 (C-4'), 144.9 (C-8'a), 152.0 (C-8a), $153.4\left(\mathrm{C}-2^{\prime}\right), 157.4$ (C-6'), 160.9 (C-2), 166.4 (C-4). DCI-HRMS [M+H] ${ }^{+}$calcd. for $\left(\mathrm{C}_{20} \mathrm{H}_{16} \mathrm{NO}_{4}\right)^{+}:$334.1079, found 334.1084.

\subsubsection{3-(7-Chloroquinolin-2-yl)-4-Hy- droxy-2H-Chromen-2-One (5f)}

Yield: 63\%, MP: $280-282{ }^{\circ} \mathrm{C},{ }^{1} \mathrm{H}$ NMR $(300 \mathrm{MHz}$, DMSO$\left.d_{6}, \delta\right): 7.14\left(\mathrm{~d}, 1 \mathrm{H}, \mathrm{H}-3^{\prime}, J=6.0 \mathrm{~Hz}\right), 7,22\left(\mathrm{~m}, 4 \mathrm{H}, \mathrm{H}-5,6,8,8^{\prime}\right)$, $7.63(\mathrm{t}, 1 \mathrm{H}, \mathrm{H}-7, J=6.0 \mathrm{~Hz}), 7,95\left(\mathrm{~d}, 1 \mathrm{H}, \mathrm{H}-5^{\prime}, J=6.0 \mathrm{~Hz}\right)$, $8.59\left(\mathrm{~d}, 1 \mathrm{H}, \mathrm{H}-4^{\prime}, J=6.0 \mathrm{~Hz}\right), 11,18(\mathrm{~s}, 1 \mathrm{H}, \mathrm{OH}) ;{ }^{13} \mathrm{C} \mathrm{NMR}$ (75 MHz, DMSO- $d_{6}, \delta$ ): $97.1(\mathrm{C}-3), 116.4$ (C-8), 117.0 (C-4a), 118.4 (C-3'), 123.3 (C-5), 124.4 (C-5'), 125.3 (C-6), 128.0 (C-7), 127.4 (C-4'a), 127.9 (C-6'), 129.3 (C-8'), 135.1 (C-7'), 136.2 (C-4'), 147.0 (C-8'a), 152.1 (C-8a), 159.8 (C-2'), 161.0 (C-2), 166.5 (C-4). DCI-HRMS [M+H] ${ }^{+}$calcd. for $\left(\mathrm{C}_{18} \mathrm{H}_{11} \mathrm{ClNO}_{3}\right)^{+}:$324.0427, found 324.0435.

\section{Biological}

\subsection{Anti-tyrosinase Activity}

The effect of inhibitor on mushroom tyrosinase was measured using L-tyrosine (1 $\mathrm{mM})$ as the substrate. Hydroquinone $(1 \mathrm{mM})$ was chosen as tyrosinase inhibitor. Both substrate and inhibitor were prepared in $0.1 \mathrm{M}$ phosphate buffer $\mathrm{pH}$ 6.5. Inhibition of tyrosinase activity was tested in a reaction mixture $(4 \mathrm{~mL})$ containing $1.960 \mathrm{~mL}$ phosphate buffer, $2 \mathrm{~mL}$ L-tyrosine $(1 \mathrm{mM}), 20 \mu \mathrm{L}$ mushroom tyrosinase and $20 \mu \mathrm{L}$ hydroquinone $(1 \mathrm{mM})$. The reaction was initiated by addition of enzyme to the solution of substrate and inhibitor. Then, the reaction cell and all solutions were both thermostated at $25{ }^{\circ} \mathrm{C}$. Inhibition effect was determined by the diminution of the maximum quantity of dopachrome formed and the absorbance was measured spectrophotometrically at $475 \mathrm{~nm}$. The inhibition percentage of tyrosinase activity was calculated as: Inhibition $(\%)=(\mathrm{A}-\mathrm{B}) / \mathrm{A} \times 100$. Where A represents the optical density of the tyrosinase enzyme and $\mathrm{B}$ represents the optical density of the tested samples during $30 \mathrm{~min}$. The assay was carried out in triplicate and Kojic acid was used as positive control agent. Sample concentration providing $50 \%$ inhibition $\left(\mathrm{IC}_{50}\right)$ was obtained plotting the inhibition percentage against sample concentrations [27].

\subsection{Anti-butyrylcholinesterase Activity}

Human plasma (pool plasma from samples designated for biochemical analysis) was used as a source of BChE. 100 $\mu \mathrm{L}$ of each sample were added to $100 \mu \mathrm{L}$ of plasma and the mixture was incubated at $37{ }^{\circ} \mathrm{C}$ for $15 \mathrm{~min}$. After incubation, the enzyme activity was measured by Konelab $30 \AA$ UV apparatus at $405 \mathrm{~nm}$. The control (plasma and distilled water) was treated in the same conditions. The assay was achieved in duplicate. Galanthamine was chosen as control positive. The anti-butyrylcholinesterase activity was calculated using the following formula: \% Inhibition $=[$ (Activity of control-Activity of sample)/Activity of control] $\times 100$. The sample concentration providing $50 \%$ inhibition $\left(\mathrm{IC}_{50}\right)$ was determined by plotting inhibition percentages against concentrations of the sample. To evaluate temperature and incubation times effects, assays were performed by using the same procedure for the same sample, at $25^{\circ} \mathrm{C}$ (fixed incubation times) and for different times at $37^{\circ} \mathrm{C}$ [28].

\subsection{Molecular Docking Procedure}

The three-dimensional structures of PDB (PDB: 2Y9W) and PDB (PDB: 4TPK) were obtained from the RSCB protein data bank $[29,30]$. Before conducting the docking procedure, the original ligands and water molecules were removed. The polar hydrogens were then added to the enzyme structure. The optimization of all the geometries of scaffolds was performed with ACD (3D viewer) software (http://www.filefacts.com/acd3d-viewer-freeware-info). Molecular docking of the studied chemical compounds 5a, $\mathbf{5 c}, \mathbf{5 d}, \mathbf{5 e}$, and $\mathbf{5 f}$ at the tropolone-binding site was performed using autodock Vina software [31]. The analysis of intermolecular interactions has been performed using Pymol Version $0.99 \mathrm{rc} 6$.

\section{Results and Discussion}

\subsection{Chemistry}

We used DMF-DMA as a key reagent because of its high reactivity $[25,26]$. 4-Hydroxy-3-(quinolin-2-yl)-2 $\mathrm{H}$ chromen-2-one derivatives 5a-f were synthesized through a four-step reaction (Scheme 1). The 3-acetyl-4-hydroxycoumarin 2 obtained by acetylation of 4-hydroxycoumarin 
Scheme 1 Synthesis of4hydroxy-3-(quinolin-2-yl)- $2 H$ chromen-2-ones 5a-f. Reaction conditions: (i) Acetic anhydride, pyridine, $150{ }^{\circ} \mathrm{C}$, reflux $2 \mathrm{~h}$; (ii) Aromatic amines, $\mathrm{EtOH}$, $79{ }^{\circ} \mathrm{C}$, reflux $4 \mathrm{~h}$; (iii) DMFDMA (2 eq), Toluene, $110^{\circ} \mathrm{C}$, reflux 10 min; (iv) Acetic acid, $117^{\circ} \mathrm{C}$, reflux $1 \mathrm{~h}$

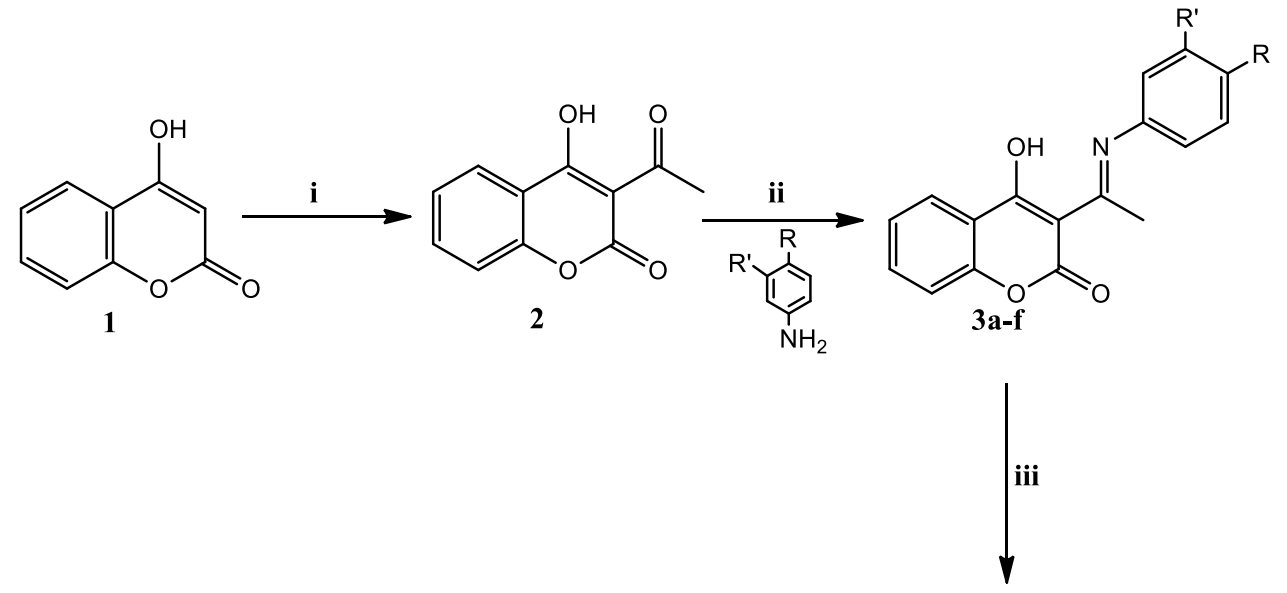<smiles></smiles>

1 was condensed with a series of primary aromatic amines, in ethanol, for $4 \mathrm{~h}$ to afford compounds $\mathbf{3}$. Compounds 4a-f, prepared by treating 3 with DMF-DMA in toluene for $10 \mathrm{~min}$, were heated in acetic acid for $1 \mathrm{~h}$ to produce the target compounds 5a-f (Table 1).

Mechanically, the formation of compound 5 (Scheme 2) starts by the protonation of dimethyl nitrogen in intermediates 4 , the free doublet of nitrogen $\mathrm{N}_{1}$, being engaged in an intramolecular hydrogen bond with the $\mathrm{OH}$ group of the coumarin moiety. Cyclization of this intermediate was made possible by an intramolecular rearrangement similar to that of Diels-Alder reactions, thus producing the 5a-f derivatives after aromatization and departure of an NHMe2 molecule. The structures of substituted 4-hydroxy-3-(quinolin2-yl)-2H-chromen-2-one derivatives $\mathbf{5 a}-\mathbf{f}$, were assigned on the basis of on their ${ }^{1} \mathrm{H}$ and ${ }^{13} \mathrm{C}$ NMR spectral data. The DCI-HRMS mass spectra of all the compounds were consistent with the proposed structures.

\subsection{Biological}

Compounds $\mathbf{4}$ and $\mathbf{5}$ were evaluated for their anti-tyrosinase and anti-butyrylcholinesterase activities.

\subsubsection{Anti-tyrosinase Inhibitory}

The anti-tyrosinase activity of compounds $4 \mathbf{a}-\mathbf{f}$ and $\mathbf{5 a}-\mathbf{f}$ was carried. The results clearly indicated that compounds 5a-f were more active than their precursors $4 \mathbf{a}-\mathbf{f}$, demonstrating the net contribution importance of the formed quinoline system, which appeared to be involved in the inhibition of tyrosinase (Table 2). Compounds 5a, 5c, $\mathbf{5 e}$, and $\mathbf{5 f}$ were found to display remarkable tyrosinase inhibiting abilities $\left(\mathrm{IC}_{50}=17.5 \pm 1.0,18.3 \pm 0.5,17.9 \pm 0.7\right.$ and $15.1 \pm 0.8 \mu \mathrm{M}$, respectively) compared to the positive control kojic acid $\left(\mathrm{IC}_{50}=12.1 \pm 0.2 \mu \mathrm{M}\right)$. The compound $5 \mathbf{f}$ with a chlorine atom in $\mathrm{C}_{7}$ position showed the highest activity. The unsubstituted quinoline 5a displayed an important activity. This finding shows the importance of the chlorine atom in $\mathbf{5 f}$ which is certainly at the origin of the improvement of this activity. On the other hand, by comparing the activity of analogues $\mathbf{5 b}\left(\mathrm{R}=\mathrm{Cl}, \mathrm{R}^{\prime}=\mathrm{H}\right)$ $\left(\mathrm{IC}_{50}=28.7 \pm 1.1 \mu \mathrm{M}\right)$ and $\mathbf{5 f}\left(\mathrm{R}=\mathrm{H}, \mathrm{R}^{\prime}=\mathrm{Cl}\right)$, we can clearly see the influence of this position on the activity. Indeed, the chlorine in the meta-position was found to be more effective in terms of anti-tyrosinase activity. The inductive and mesomeric electronic effects exerted by the chlorine atom in each position could be at the origin of this difference in activity. The compound $\mathbf{5 c}$ with a methyl group at $\mathrm{C}_{6^{\prime}}$, and the unsubstituted compound $\mathbf{5 a}$, exhibited a comparable anti-tyrosinase effect, this suggests that the methyl group cannot be considered as a good candidate substituent which can improve this activity. Compound 5d with a methoxy at $\mathrm{C}_{6}$, was found to be less active $\left(\mathrm{IC}_{50}=24.9 \pm 1.1 \mu \mathrm{M}\right)$ than its analog $5 \mathbf{e}$ with an ethoxy group in the same position. This result shows clearly the 
Table 1 Compounds $\mathbf{4 a}-\mathbf{f}$ and $\mathbf{5 a}-\mathbf{f}$ : structures and yields

\begin{tabular}{|c|c|c|c|c|c|}
\hline Entry & Product & Main structure of compounds & $\mathrm{R}$ & $\mathrm{R}^{\prime}$ & Yields $(\%)$ \\
\hline 1 & $4 \mathbf{a}$ & & $\mathrm{H}$ & $\mathrm{H}$ & 53 \\
\hline 2 & $4 b$ & & $\mathrm{Cl}$ & $\mathrm{H}$ & 63 \\
\hline 3 & $4 c$ & & $\mathrm{Me}$ & $\mathrm{H}$ & 60 \\
\hline 4 & 4d & & $\mathrm{OMe}$ & $\mathrm{H}$ & 57 \\
\hline 5 & $4 e$ & & OEt & $\mathrm{H}$ & 61 \\
\hline 6 & $4 f$ & & $\mathrm{H}$ & $\mathrm{Cl}$ & 76 \\
\hline 7 & $5 \mathbf{a}$ & & $\mathrm{H}$ & $\mathrm{H}$ & 52 \\
\hline 8 & $\mathbf{5 b}$ & & $\mathrm{Cl}$ & $\mathrm{H}$ & 71 \\
\hline 9 & $5 c$ & & $\mathrm{Me}$ & $\mathrm{H}$ & 45 \\
\hline 10 & 5d & & $\mathrm{OMe}$ & $\mathrm{H}$ & 75 \\
\hline 11 & $5 e$ & & OEt & $\mathrm{H}$ & 48 \\
\hline 12 & $5 f$ & & $\mathrm{H}$ & $\mathrm{Cl}$ & 63 \\
\hline
\end{tabular}

influence of the nature of the alkoxy group attached at $\mathrm{C}_{6^{\prime}}$ position on this activity.

The results described above clearly show the contribution of the quinoline fragment introduced to have this activity compared with that of the precursors $\mathbf{4 a - f}$. This finding agrees well with the literature data showing the significant activity of quinoline derivatives, such as chloroquine [16] with a chlorine atom at the same position as the more active $\mathbf{5 f}$ derivative of the series $\mathbf{5}$.

\subsubsection{Anti-butyrylcholinesterase Activity}

Compounds 5a-f and their precursors $4 \mathbf{a}-\mathbf{f}$ were assessed using an anti-butyrylcholinesterase test and the $\mathrm{IC}_{50}$ values are indicated in Table 3 . The compounds $\mathbf{4 a - f}$ were found to be less active than $\mathbf{5 a}-\mathbf{f}$ ones. These results revealed the importance of cyclization, leading to the formation of quinoline, which appeared to be involved in the inhibition of BChE. The compound 5d with a methoxy group exhibited the highest anti-BChE effect with an $\mathrm{IC}_{50}$ value of $40.0 \pm 0.4 \mu \mathrm{M}$, followed by the derivative $\mathbf{5 f}$ with a chlorine atom at $\mathrm{C}_{7^{\prime}}\left(\mathrm{IC}_{50}=51.0 \pm 0.5 \mu \mathrm{M}\right)$. The activity of the later compared to that of its analogue $\mathbf{5 b}$ with a chlorine atom at $\mathrm{C}_{6^{\prime}}\left(\mathrm{IC}_{50}=89.0 \pm 0.8 \mu \mathrm{M}\right)$ allows to notice the influence of the position of the chlorine atom on this activity. The activity of these two chlorinated derivatives $\mathbf{5 f}$ and $\mathbf{5 b}$ compared to that of the unsubstituted compound 5a $\left(\mathrm{IC}_{50}=112.0 \pm 2.0 \mu \mathrm{M}\right)$, shows the importance of the chlorine atom whatever its position in improving this activity. The inductive and mesomeric electronic effects exerted by the chlorine atom in each position could explain this difference in activity. On the other hand, the compound $\mathbf{5 d}$ with a methoxy group at $\mathrm{C}_{6}$, showed twice the activity of its analogue $5 \mathbf{e}\left(\mathrm{IC}_{50}=79.0 \pm 0.5 \mu \mathrm{M}\right)$ with an ethoxy group at the same position $\left(\mathrm{IC}_{50}=79.0 \pm 0.5 \mu \mathrm{M}\right)$. This showed that we may not need to extend the alkyl group of the alkoxy moiety to obtain better activity. Testing other compounds with longer alkoxy groups is necessary to provide greater support 
Scheme 2 Plausible mechanism for the formation of compounds 5a-f<smiles>[R]c1cccc(N2[CH]Oc3c(c(=O)oc4ccccc34)C2/C=C/N(C)C)c1</smiles>

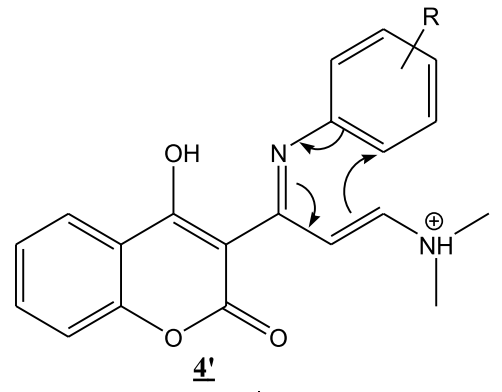

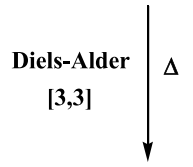<smiles>[R][X]c1ccc2nc(-c3c(O)c4ccccc4oc3=O)ccc2c1</smiles>

$\underline{\mathbf{5}(\mathbf{a}-\mathbf{f})}$

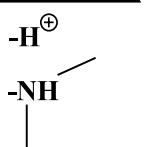

(n)
Table 2 Anti-tyrosinase activity of compounds $4 \mathbf{a}-\mathbf{f}$ and $\mathbf{5 a}-\mathbf{f}$

\begin{tabular}{lc}
\hline Compound & $\mathrm{IC}_{50}(\mu \mathrm{M})^{\mathrm{a}}$ \\
\hline $\mathbf{4 a}$ & $102.0 \pm 2.0$ \\
$\mathbf{4 b}$ & $>100$ \\
$\mathbf{4 c}$ & $>100$ \\
$\mathbf{4 d}$ & $>100$ \\
$\mathbf{4 e}$ & $95.2 \pm 3.3$ \\
$\mathbf{4 f}$ & $81.8 \pm 1.9$ \\
$\mathbf{5 a}$ & $17.5 \pm 1.0$ \\
$\mathbf{5 b}$ & $28.7 \pm 1.1$ \\
$\mathbf{5 c}$ & $18.3 \pm 0.5$ \\
$\mathbf{5 d}$ & $24.9 \pm 1.1$ \\
$\mathbf{5 e}$ & $17.9 \pm 0.7$ \\
$\mathbf{5 f}$ & $15.1 \pm 0.8$ \\
Kojic acid & $12.1 \pm 0.2$ \\
\hline The concentration & of com- \\
pound that inhibits & $50 \%$ of the \\
enzyme (mean $\pm \mathrm{SD}, \mathrm{n}=3)$
\end{tabular}

for this conclusion. The relatively weak activity of compound $\mathbf{5 c}$ with a methyl group at $\mathrm{C}_{6^{\prime}}\left(\mathrm{IC}_{50}=99.0 \pm 1.0 \mu \mathrm{M}\right)$ when compared to the rest of the substituted derivatives leads to the conclusion that this methyl group is not much involved in the possible interactions between the ligand and the amino acids of the enzyme.

The contribution of the introduced quinoline moiety to the anti-BChE activity of the $\mathbf{5 a - f}$ compounds is defended
Table 3 Anti-butyrylcholinesterase activity of compounds $\mathbf{4 a - f}$ and 5a-f

\begin{tabular}{lr}
\hline Compound & $\mathrm{IC}_{50}(\mu \mathrm{M})^{\mathrm{a}}$ \\
\hline $\mathbf{4 a}$ & $233.0 \pm 3.8$ \\
$\mathbf{4 b}$ & $154.0 \pm 2.6$ \\
$\mathbf{4 c}$ & $198.0 \pm 2.7$ \\
$\mathbf{4 d}$ & $144.0 \pm 2.6$ \\
$\mathbf{4 e}$ & $150.0 \pm 3.1$ \\
$\mathbf{4 f}$ & $167.0 \pm 3.0$ \\
$\mathbf{5 a}$ & $112.0 \pm 2.0$ \\
$\mathbf{5 b}$ & $89.0 \pm 0.8$ \\
$\mathbf{5 c}$ & $99.0 \pm 1.0$ \\
$\mathbf{5 d}$ & $40.0 \pm 0.4$ \\
$\mathbf{5 e}$ & $79.0 \pm 0.5$ \\
$\mathbf{5 f}$ & $51.0 \pm 0.5$ \\
Galanthamine & $380 \times 10^{-3} \pm 0.002 \times 10^{-3}$ \\
\hline
\end{tabular}

${ }^{\mathrm{a}}$ The concentration of compound that inhibits $50 \%$ of the cell proliferation (mean $\pm \mathrm{SD}, \mathrm{n}=3$ )

by the data from the literature which show that quinolinebased scaffold, once introduced into a molecule, improves its anti-BChE potential [29]. 


\section{The Molecular Docking Studies}

\subsection{Molecular Docking Analysis for Anti-tyrosinase Activity (PDB: 2Y9W)}

Tyrosinase (PDB code: $2 \mathrm{Y} 9 \mathrm{~W}$ ) is a tetrameric protein composed of four chains $(\mathrm{A}, \mathrm{B}, \mathrm{C}$, and D) with the sequence length of 391. This binuclear copper-containing enzyme catalyzes the conversion of monophenol (tyrosine) and o-diphenol (L-DOPA) to the corresponding o-quinone derivative [30].

Molecular modeling studies were carried out by using Autodock Vina software [31] to understand the interactions of synthesized compounds $\mathbf{5 a}-\mathbf{f}$ within the hydrophobic binding pocket of tropolone (PDB: $2 \mathrm{Y} 9 \mathrm{~W}$ ), and to investigate the binding modes and binding energies (Table 4) that lead to the observed SARs and differences in $\mathrm{IC}_{50}$
The analyses of binding affinities and molecular interactions for the 4-hydroxy-3-(quinolin-2-yl)-2H-chromen-2-one derivatives found $\mathbf{5 a}, \mathbf{5 c}, \mathbf{5 e}$, and $\mathbf{5 f}$ were the most active. As Table 4 indicates, the values of binding energy of these derivatives are higher than that of the control (kojic acid).

The SARs of the anti-tyrosinase agents in Fig. 1 support that compound 5a exercises through its coumarinic fragment a pi sigma interaction (dark purple color) with VAL-A-248, a conventional hydrogen bond interaction (green color) with HIS-A-244 and by its quinoline fragment a pi-pi stacking (dark pink color) with PHE-A-264 and pi alkyl interaction (light pink color) with VAL-A-283. Derivative 5c forms some hydrophobic interactions with VAL-A-248 and VALA-283 (pi sigma), HIS-A-259 (pi-pi shaping (dark pink color)), HIS-A-263 (pi-pi stacking), SER-A-282 (amide pi stacking (dark pink color)), ALA-A-286 (pi alkyl interaction), VAL-A-248 (alkyl interactions (light pink color)) and with HIS-A-85 (carbon hydrogen bond (grey color)) (Fig. 1). Further, compound $\mathbf{5 e}$ is involved in pi alkyl interactions
Table 4 Binding affinity of promising anti-tyrosinase agents towards amino acid residuals
Fig. 1 Binding pose of conjugates $\mathbf{5 a}, \mathbf{5 c}$ and $\mathbf{5 e}$ in the tropolone binding cavity of PDB: 2Y9W.

\begin{tabular}{lrrrrrr}
\hline Binding energy $(\mathrm{kcal} / \mathrm{mol})$ & & & & & \\
5a & -7.5 & -7.5 & -6.7 & -6.7 & -6.5 & -6.0 \\
$\mathbf{5 c}$ & -7.4 & -7.0 & -6.9 & -6.0 & -6.0 & -5.8 \\
$\mathbf{5 e}$ & -7.9 & -7.2 & -6.9 & -6.5 & -6.5 & -6.2 \\
$\mathbf{5 f}$ & -8.2 & -8.0 & -7.2 & -7.2 & -6.7 & -6.4 \\
Kojic acid & -5.7 & -5.4 & -5.2 & -5.0 & -5.0 & -4.9 \\
\hline
\end{tabular}

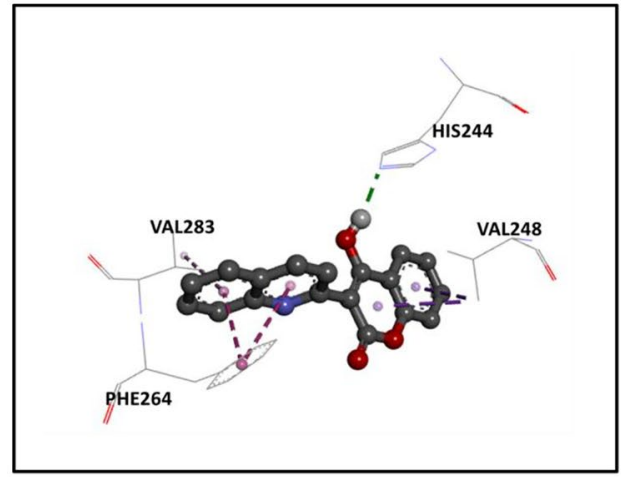

$5 a$

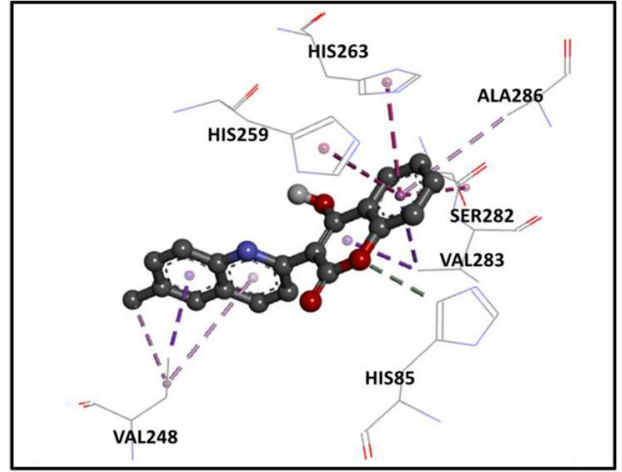

5c

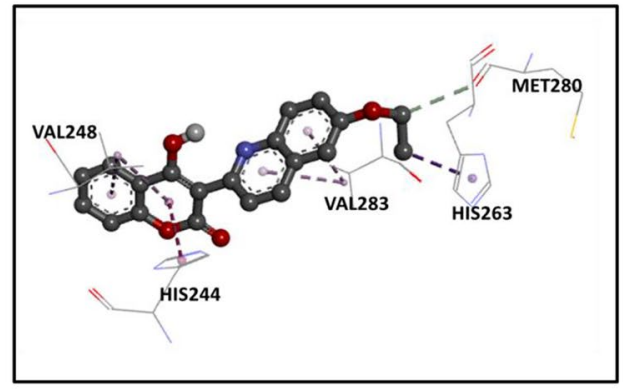


with VAL-A-248 and VAL-A-283. Besides, it displayed a pi-pi shaping with HIS-A-244, a pi sigma interaction with HIS-A-263 and carbon hydrogen bond with MET-A-280 (Fig. 1).

The most effective anti-tyrosinase agent $\mathbf{5 f}$ having the lowest binding affinity (Table 4) established interactions with residues HIS-A-244, VAL-A-248, HIS-A-263 and PHE-A-264 and VAL-A-283. In details, 5f was strongly bound by the hydroxyl functional group with HIS-A-244 in conventional hydrogen bond interactions, pi sigma interaction with VAL-A-248, pi-pi stacking with PHE-A-264, alkyl and pi alkyl interactions with HIS-A-263, PHE-A-264 andVAL-A-283 (Fig. 2).

\subsection{Molecular Docking Analysis for Anti-butyrylcho- linesterase Activity (PDB: 4TPK)}

To understand the anticholinesterase potential of derivative 5d, binding interactions between ligand and butyrylcholinesterase BChE (PDB: 4TPK (chain A)) were analyzed [32]. Molecular docking analysis was performed using Autodock Vina software [31]. Figure 3 showed that hydroxycoumarin is involved in conventional hydrogen bonding (green color) by its hydroxyl functional groups with SER-A-198 and pi-pi shaping interactions (dark pink color) with TRP-A-231 and PHE-A-329 besides to pi alkyl interaction (light pink color) with LEU-A-286. Further, methoxyquinoline ring forms amide pi stacking interaction (dark pink color) with GLY-A-116, pi-pi shaping interaction with TRPA-82, pi donor hydrogen bond with THR-A-120 and carbon hydrogen bond (grey color) with GLN-A-67.

\section{Conclusion}

In summary, we develop here a simple and easy method to synthesize heterocyclic compounds in a short time and with good yields. This was achieved by including quinoline and 4-hydroxycoumarin moieties in their structure, using DMFDMA as the main reagent. We examined the anti-tyrosinase and anti-butyrylcholinesterase activities of these prepared heterocycles and some of them exhibited interesting antityrosinase and butyrylcholinesterase activities. Molecular docking analyses lead to the conclusion that the quinoline
Fig. 2 Docking pose of compound $\mathbf{5 f}$ (most effective antityrosinase agent) in the active site of tropolone hydrophobic cavity of PDB: 2Y9X
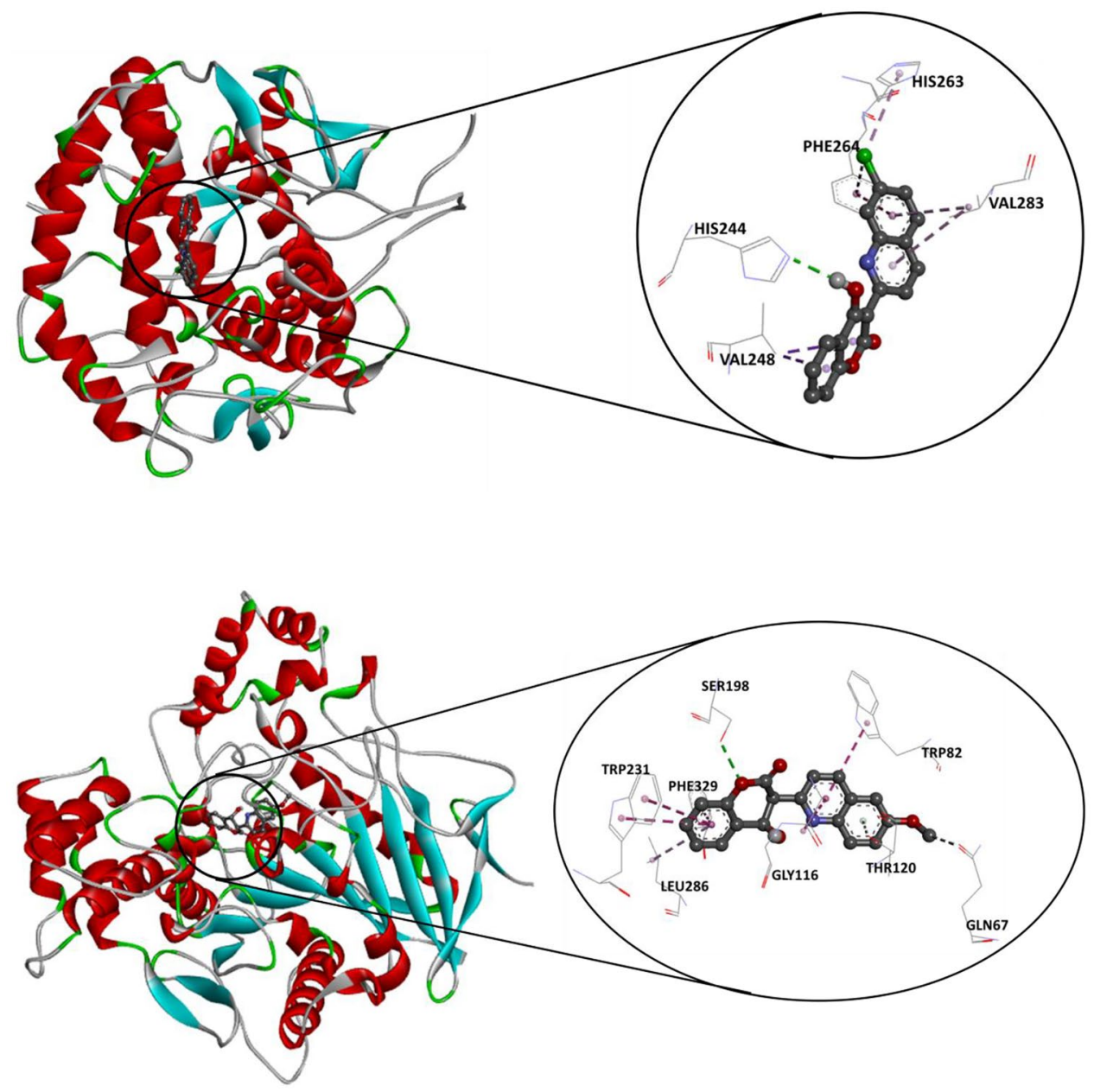

Fig. 3 Docking pose of compound $\mathbf{5 d}$ in the active site of BChE (PDB: 4TPK) 
moiety is essential for the build-up and improvement of anti-tyrosinase and anti-butyrylcholinesterase activities of conjugates $\mathbf{5 a}-\mathbf{f}$. In silico $S A R$ studies were found in good agreement with biological evaluation showing that the nature of the substitute on the quinoline ring is essential to give significant binding interaction with amino acids of enzymes. The chlorine atom appears to be in favor with the activities studied. The diversification of its position and its number merit further study.

Acknowledgements The authors are grateful to the Ministry of Higher Education and Scientific Research of Tunisia for financial support (LR11ES39).

\section{Compliance with Ethical Standards}

Conflict of interest The authors declare that they no conflict of interest.

\section{References}

1. DeTure MA, Dickson DW (2019) The neuropathological diagnosis of Alzheimer's disease. Mol Neurodegeneration 14:32-49. https://doi.org/10.1186/s13024-019-0333-5

2. Stanciu GD, Luca A, Rusu RN, Bild V, Chiriac SIB, Solcan C, Bild W, Ababei DC (2020) Alzheimer's disease pharmacotherapy in relation to cholinergic system involvement. Biomolecules 10:40-59. https://doi.org/10.3390/biom 10010040

3. BrintonR D, YamazakiRS, (1998) Advances and challenges in the prevention and treatment of Alzheimer's disease. Pharm Res 15:386-389

4. Pourabdi L, Khoobi M, Nadri H, Moradi A, Moghadam FH, Emami S, Mojtahedi MM, Haririan I, Forootanfar H, Ameri A, Foroumadi A, Shafiee A (2016) Synthesis and structure activity relationship study of tacrine-based pyrano [2.3-c]pyrazoles targeting AchE/BuchEand 15-LOX. Eur J Med Chem 123:298-308. https://doi.org/10.1016/j.ejmech.2016.07.043

5. Benchekroun M, Ismaili L, Pudlo M, Luzet V, Gharbi T, Refouvelet B, Marco-Contelles J (2015) Donepezil-ferulic acid hybrids as anti-Alzheimer drugs. Future Med Chem 7:15-21. https://doi. org/10.4155/fmc. 14.148

6. Simon A, Amaro MI, Healy AM, Cabral LM, de Sousa VP (2016) Comparative evaluation of rivastigmine permeation from a transdermal system in the Franz cell using synthetic membrane and pig ear skin with in vivo-in vitro correlation. Int J Pharm 512:234241. https://doi.org/10.1016/j.ijpharm.2016.08.052

7. Sanli N, Bulduk I, Ozkurt H, Şanli S, Ozkan SA (2016) Development and validation of capillary zone electrophoretic method for rapid and sensitive determination of galanthamine: application in plants and pharmaceuticals. J Pharm Biomed Anal 131:188-194. https://doi.org/10.1016/j.jpba.2016.08.026

8. Zajdel P, Marciniec K, Maślankiewicz A, Grychowska K, Satała G, Duszyńska B, Lenda T, Siwek A, Nowak G, Partyka A, Wróbel D, Jastrzębska-Więsek M, Bojarski AJ, Wesołowska A, Pawłowski M (2013) Antidepressant and antipsychotic activity of new quinolone and isoquinoline-sulfonamide analogs of aripiprazole targeting serotonin 5- $\mathrm{HT}_{1} \mathrm{~A} / 5-\mathrm{HT}_{2} \mathrm{~A} / 5-\mathrm{HT}_{7}$ and dopamine $\mathrm{D}_{2} / \mathrm{D}_{3}$ receptors. Eur J Med Chem 60:42-50. https://doi.org/10.1016/j. ejmech.2012.11.042

9. Rampa A, Bisi A, Belluti F, Gobbi S, Valenti P, Andrisano V, Cavrini V, Cavalli A, Recanatini M (2000)
Acetylcholinesterase inhibitors for potential use in Alzheimer's disease: molecular modeling, synthesis and kinetic evaluation of $11 \mathrm{H}$-indeno-[1,2- $b]$-quinolin-10-ylamine derivatives. Bioorg Med Chem Lett 8:497-506. https://doi.org/10.1016/s0968 -0896(99)00306-5

10. Zhong W, Liu H, Kaller MR, Henley C, Magal E, Nguyen T, Osslund TD, Powers D, Rzasa RM, Wang HL, Wang W, Xiong X, Zhang J, Norman MH (2007) Synthesis and design of quinolin-2(1H)-one derivatives as potent CDK5 inhibitors. Bioorg Med Chem Lett 17:5384-5389. https://doi.org/10.1016/j. bmcl.2007.07.045

11. Oset-Gasque MJ, González MP, Pérez-Peña J, García-Font N, Romero A, del Pino J, Ramos E, Hadjipavlou-Litina D, Soriano E, Chioua M, Samadi A, Raghuvanshi DS, Singh KN, MarcoContelles J (2014) Toxicological and pharmacological evaluation antioxidant, ADMET and molecular modelingof selected racemic chromenotacrines 11 amino-12-aryl-8,9,10,12-tetrahydro7H-chromeno[2,3-b]quinolin-3-ols for the potential prevention and treatment of Alzheimer's disease. Eur J Med Chem 74:491501. https://doi.org/10.1016/j.ejmech.2013.12.021

12. Murru S, Gough BM, Srivastava RS (2014) Synthesis of substituted quinolines via allylic amination and intermolecular Heck coupling. Org Biomol Chem 12:9133-9138

13. Selig P, Raven W (2014) A convenient alenoate-based synthesis of 2-quinolin-2-one malonates and $\beta$-ketoesters. Org Lett 16:51925195. https://doi.org/10.1021/ol502554e

14. Zhou S, Ren J, Liu M, Ren L, Liu Y, Gong P (2014) Design, synthesis and pharmacological evaluation of 6,7-disubstituted-4-phenoxyquinoline derivatives as potential antitumor agents. Bioorg Chem 57:30-42. https://doi.org/10.1016/j.bioorg.2014.07.011

15. Xuan DD (2019) Recent progress in the synthesis of quinolines 16:671-708. https://doi.org/10.2174/15701794166661907191 12423

16. Ni-Komatsu L, Tong C, Chen G, Brindzei N, Orlow SJ (2008) Identification of quinolines that inhibit melanogenesis by altering tyrosinase family trafficking. Mol Pharmacol 74:1576-1586. https ://doi.org/10.1124/mol.108.050633

17. Lin JY, Fisher DE (2007) Melanocyte biology and skin pigmentation. Nature 445:843-850

18. Gupta AK, Gover MD, Nouri K, Taylor S (2006) The treatment of melasma: a review of clinical trials. Am Acad Dermatol 55:10481065. https://doi.org/10.1016/j.jaad.2006.02.009

19. Jung JC, Lee JH, Oh S, Lee JG, Park OS (2004) Synthesis and antitumor activity of 4-hydroxycoumarin derivatives. Bioorg Med Chem Lett 14:5527-5531. https://doi.org/10.1016/j. bmcl.2004.09.009

20. Abdelhafez OM, Amin KM, Batran RZ, Maher TJ, Nada SA, Sethumadhavan S (2010) Synthesis, anticoagulant and PIVKAII induced by new 4-hydroxycoumarin derivatives. Bioorg Med Chem 18:3371-3378. https://doi.org/10.1016/j.bmc.2010.04.009

21. Timonen JM, Nieminen RM, Sareila O, Goulas A, Moilanen LJ, Haukka M, Vainiotalo P, Moilanen E, Aulaskari PH (2011) Synthesis and anti-inflammatory effects of a serie of novel 7-hydroxycoumarin derivatives. Eur J Med Chem 46:3845-3850. https://doi. org/10.1016/j.ejmech.2011.05.052

22. Li J, Hou Z, Li F, Zhang Z, Zhou Y, Luo X, Li M (2014) Synthesis, photoluminescent, antibacterial and theoretical study of 4-hydroxycoumarin derviatives. Mol Str 1075:509-514. https:// doi.org/10.1016/j.molstruc.2014.07.010

23. Kurt BZ, Gazioglu I, Sonmez F, Kucukislamoglu M (2015) Synthesis, antioxidant and anticholinesterase activities of novel coumarylthiazole derivatives. Bioorg Chem 59:80-90. https://doi. org/10.1016/j.bioorg.2015.02.002

24. Promden W, Viriyabancha W, Monthakantirat O, Umehara K, Noguchi H, De-Eknamkul W (2018) Correlation between the potency of flavonoids on mushroom tyrosinase inhibitory activity 
and melanin synthesis in melanocytes. Molecules 23:1403-1413. https://doi.org/10.3390/molecules23061403

25. Wu L, Liu B, Li Q, Chen J, Tao L, Hu G (2012) Design, synthesis and anti-fibrosis activity study of N1-substituted phenylhydroquinolone derivatives. Molecules 17:1373-1387. https://doi. org/10.3390/molecules 17021373

26. Zghab I, Trimeche B, Touboul D (2014) A regioselective 1,3-dipolar cycloaddition for the synthesis of novel spiro-chromenethiadiazole derivatives. C R Chimie 17:171-178. https://doi. org/10.1016/j.crci.2013.08.004

27. Zardi-Bergaoui A, Jelassi A, Daami-Remadi M, Harzallah-Skhiri F, Flamini G, Ascrizzi R, Ben Jannet H (2019) Chemical composition and bioactivities of essential oils from Pulicaria vulgaris subsp. dentata (Sm.) Batt. growing in Tunisia. J Essent Oil Res, 111-120. https://doi.org/10.1080/10412905.2019.1698468.

28. Aissa I, Nimbarte VD, Zardi-Bergaoui A, Znati M, Flamini G, Ascrizzi R, Ben Jannet H (2019) Isocostic acid, a promising bioactive agent from the essential oil of Inula viscosa (L.) :insights from drug likeness properties, molecular docking, and SAR analysis. Chem Biodiversity 16:e1800648. https://doi.org/10.1002/ cbdv.201800648.
29. Mo J, Yang H, Chen T, Li Q, Lin H, Feng F, Liu W, Qu W, Guo Q, Chi H, Chen Y, Sun H (2019) Design, synthesis, biological evaluation, and molecular modeling studies of quinoline-ferulic acid hybrids as cholinesterase inhibitors. Bioorg Chem 93:103310. https://doi.org/10.1016/j.bioorg.2019.103310

30. Ismaya WT, Rozeboom HJ, Weij A, Mes JJ, Fusetti F, Wichers HJ, Dijkstra BW (2011) Crystal structure of Agarius bisporus Mushroom Tyrosinase: identity of the tetramer subunits and interaction with tropolone. Biochemistry 50:5477-5486. https://doi. org/10.1021/bi200395t

31. Trott O, Olson AJJ (2010) Autodock Vina: improving the speed and accuracy of dockinh with a new scoring function, efficient optimization, and multithreading. Comput Chem 31:455-461. https://doi.org/10.1002/jcc.21334

32. Brus B, Kosa U, Turk S, Pislar A, Coquelle N, Kos J, Stojan J, Colletier JP, Gobec S (2014) Discovery, biological evaluation, and crystal structure of a novel nanomolar selective butyrylcholinesterase inhibitor. J Med Chem 57:8167-8179. https://doi. org/10.1021/jm501195e 